
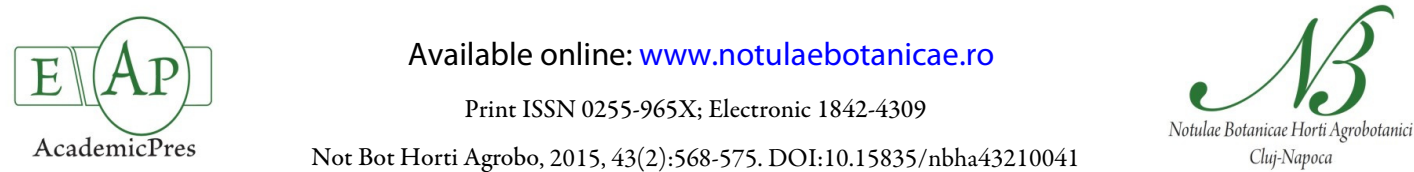

\title{
Calculating Organic Carbon Stock from Forest Soils
}

\author{
Lucian Constantin DINCĂ $\breve{1}^{1}$, Maria DINCĂ ${ }^{1}$, Diana VASILE \\ Gheorghe SPÂRCHEZ ${ }^{2}$, Liviu HOLONEC ${ }^{3 *}$ \\ ${ }^{1}$ National Forest Research-Development Institute "Marin Dracea", 13 Closca, \\ 500035 Brassov,Romania; dinka.lucian@gmail.com;maria.dincal@gmail.com;diana_vasile@ymail.com \\ ${ }^{2}$ Transilvania University of Brașov, Faculty of Silviculture and Forest Engineering, 1 Șirul Beethoven, 500123 Braşov, Romania; \\ sparchez@unitbv.ro \\ ${ }^{3}$ University of Agricultural Sciences and Veterinary Medicine, 3-5 Calea Mănăştur, 400372 Cluj-Napoca, Romania; \\ lholonec@usamvcluj.ro (" correspondingauthor)
}

\begin{abstract}
The organic carbon stock (SOC) ( $\mathrm{t} / \mathrm{ha}$ ) was calculated in different approaches in order to enhance the differences among methods and their utility regarding specific studies. Using data obtained in Romania (2000-2012) from 4,500 profiles and 9,523 soil horizons, the organic carbon stock was calculated for the main forest soils (18 types) using three different methods: 1 ) on pedogenetical horizons, by soil bulk density and depth class/horizon thickness; 2) by soil type and standard depths; 3) using regression equations between the quantity of organic $\mathrm{C}$ and harvesting depths. Even though the same data were used, the differences between the values of $\mathrm{C}$ stock obtained from the three methods were relatively high. The first method led to an overvaluation of the $\mathrm{C}$ stock. The differences between methods 1 and 2 were high (and reached 33\% for andosol), while the differences between methods 2 and 3 were smaller (a maximum of $23 \%$ for rendzic leptosol). The differences between methods 2 and 3 were significantly lower especially for andosol, arenosol and vertisol. A thorough analysis of all three methods concluded that the best method to evaluate the organic $C$ stock was to distribute the obtained values on the following standard depths: $0-10 \mathrm{~cm} ; 10-20 \mathrm{~cm} ; 20-40 \mathrm{~cm} ;>40 \mathrm{~cm}$. For each soil type, a correlation between the quantity of organic $\mathrm{C}$ and the sample harvesting depth was also established. These correlations were significant for all types of soil; however, lower correlation coefficients were registered for rendzic leptosol, haplic podzol and fluvisol.
\end{abstract}

Keywords: carbon stocks, organic carbon, pedogenetical horizons, soil types, standard depth

\section{Introduction}

Soils represent the largest carbon reservoirs in the terrestrial ecosystem, with $11 \%$ of soil organic carbon held in forest soils worldwide (Eswaran et al., 1999; Dey, 2005; Negi et al., 2013; Yuan et al., 2013). At a global level, forests store large amounts of carbon sequestered from the atmosphere and retained in living and lifeless biomass and soil (Pretince, 2001; Whithead, 2011). Over $40 \%$ of the soil carbon is found beneath forests. In Europe, forest soils store roughly 1.5 -fold more carbon than tree biomass (De Vreis, 2003- EC/UN-ECE). The carbon stored in forest soils can be directly managed to absorb or release atmospheric carbon to a degree that might have global implications (Johnson and Curtis, 2001; Paul et al., 2002; Lal, 2005).

Forest soil carbon pools are not well studied compared to aboveground carbon pools (Lal, 2005; Peltoniemi et al., 2007). The large spatial variability in forest soil organic matter has also limited the ability to predict its spatial distribution (Johnson $e t$ al., 1991; Yanai et al., 2000; Fahey et al., 2005; Whitehead, 2011). Inventory analysis and the investigation of soil organic carbon are required for soil quality assessments (Sikora and Stott, 1996) and carbon cycling predictions (Ellert et al., 2002), which are valuable tools for state and regional planning (De Vries, 2001; Amichev and Galbraith, 2004).
Estimates of forest soil organic carbon have applications in biogeochemical science, soil quality studies, $\mathrm{CO}_{2}$ sequestration technologies, as well as for emission-reduction compliance or trading with the aim of determining long-term carbon fluxes, or to manage natural resources and to design carbon sequestration strategies (Campbell et al., 2008). Efforts to study the potential of soils to regulate global warming and greenhouse gas effects by the ability of soils to store large quantities of carbon are increasing worldwide (Aticho, 2013; Stockmann et al., 2013; Jandl et al., 2014). The UNFCCC's national greenhouse gas inventory and the Kyoto Protocol on emission reductions require $\mathrm{CO}_{2}$ emissions or removal from carbon stock changes on land use and activities within the UNFCCC's Annex I countries to be reported as annual estimates over a specified period of time. In practice, it is first necessary to establish a baseline of the carbon stocks, to be able to estimate the changes in their levels. However, problems arising from soil sampling, soil variability and soil depth make this a difficult task (Swift, 2001). Furthermore, reliable national estimates are needed for international acceptance (Watson et al., 2000).

Most estimates of soil organic carbon stocks are based on extrapolations of the mean soil carbon content for broad categories of soil or vegetation types (Post et al., 1982; Sombroek et al., 1993; Kern, 1994). Although significant uncertainties exist with respect to both the estimates of the mean soil organic 
carbon content and the estimates of area for each category (Davidson and Lefebvre, 1993), regional studies are necessary to refine global estimates obtained by the aggregation of regional estimates, mainly at a country scale (Bernoux et al., 2002).

Don et al. (2011) reported the worldwide mean SOC stocks to be $106 \mathrm{Mg} \mathrm{C}^{-1}$ (up to $1 \mathrm{~m}$ depth), while Gorte (2009) reported it to be $68.75 \mathrm{Mg} \mathrm{Cha}^{-1}(1 \mathrm{~m}$ depth) in tropical forests. Hoffmann $e$ al. (2014) reported a mean of $64 \mathrm{Mg} \mathrm{C}^{-1}$ to a depth of $30 \mathrm{~cm}$ in the Rocky Mountains of Alberta, Brahim et al. (2010) reported a mean of $71.4 \mathrm{Mg} \mathrm{C} \mathrm{ha}^{-1}$ and $101 \mathrm{Mg} \mathrm{C} \mathrm{ha}^{-1}$ SOC stocks to the depth of $100 \mathrm{~cm}$ in Spain and Tunisia, respectively, while Woollen et al. (2012) found a mean SOC stock to the depth of $40 \mathrm{~cm}$ of $40.1 \mathrm{MgC} \mathrm{ha}{ }^{-1}$ for the Miombo woodlands in Mozambique.

According to Rojas et al. (2012) for soils of Southern Spain and Batjes (2002) for soils of Central and Eastern Europe, cambisols have higher SOC stocks than fluvisols and leptosols.

In Serbia, Kadovič et al. (2012) studied the regression dependence between carbon content and soil depth and found a modest correlation for dystric brown soils ( 25 profiles) and a strong correlation for eutric brown soils (31 profiles) and for eutric rankers (12 profiles).

In Romania, Dinca et al. (2012) have established the stocks of organic $\mathrm{C}$ in forest soils, based on data from forest management activity. This information was collected from pedogenetic horizons, but was translated to standard depths.

Studies in different parts of the world by Hoffmann et al. (2014), Tang et al. (2012), Grand and Lavkulich (2011), Djukic et al. (2010), Hattar et al. (2010), Egli et al. (2009), Seibert et al. (2007) and Yoo et al. (2006) established that the SOC stock increase with an increase in elevation. This has been explained by variations in dominant vegetation types and species richness with elevation (Yao et al., 2010; Giliba et al., 2011; Grand and Lavkulich, 2011; Sreekanth et al., 2013). Studies by Cambule $e t$ al., (2014) in Mozambique, Wiesmeier et al., (2012) in Germany and Aticho (2013) in Ethiopia have reported soil thickness to be among the important factors that affect SOC stocks. However, Xiaojun et al. (2013) and Wang et al., (2012) in China, Karchegani et al., (2012) in Iran, Fantappiè et al. (2011) in Italy, Djukic et al., (2010) in the Alpine region and Koulouri and Giourga (2007) in the Mediterranean region, reported the slope gradient also to be an important factor in determining spatial and temporal variation in SOC stocks.

As shown in Equation 3.2.16 from IPCC Good Practice Guidance for LULUCF, the total SOC content is obtained by summing the SOC contents of the constituent soil horizons or layers; the SOC content of each horizon or layer is calculated by multiplying the concentration of soil organic carbon in a sample ( $\mathrm{g} \mathrm{C} \mathrm{kg} \mathrm{soil}{ }^{-1}$ ), by the corresponding depth and bulk density ( $\mathrm{mg}$ $\mathrm{m}^{-3}$ ) and adjusting for the soil volume occupied by coarse fragments.

The calculations initially appear to be simple, but when they are performed problems appear because the soil samples have often been extracted from different depths. Therefore, the authors propose the identification of an optimal calculation method of organic $\mathrm{C}$ stocks for the mineral part of forest soils by comparing and analysing the results obtained from 6,334 values of organic C from Romania's forest soils using three different calculation methods.

\section{Materials and Methods}

The soil samples were taken from different regions of the Romanian territory and then analysed for $\mathrm{pH}$, carbonates, humus, organic carbon, total nitrogen, the sum of exchangeable hydrogen, the sum of exchange basis, total cationic exchange capacity, the degree of saturation, as well as $\mathrm{K}^{+}, \mathrm{Na}^{+}, \mathrm{Mg}^{++}$and $\mathrm{Ca}^{++}$contents. The hereby study is based on soil samples harvested between years 2000 and 2012 from 4,500 profiles and 9,523 horizons.

Analyses were performed by INCDS Bucharest, which implemented its own quality assurance system (e.g. $10 \%$ of samples were processed blind) and quality control, including regular participation in the European inter-calibration exercises of the FutMon Project (Cools and De Vos, 2009). The preparation of soil samples was based on the ISO 11464 method (ISO, 1994). Soil samples were air-dried to constant weight and were then grounded and sieved through a 2-mm sieve to obtain the fine-earth fraction (Cools and De Vos, 2010) for laboratory analysis, which was stored until chemically analysed. The organic carbon was established using a dry combustion method and an automatic LECO Tru Spec CN Analyser.

Currently, the SOC stock for a given soil stratum is estimated by extrapolating the SOC content per soil mass to the SOC pool per soil volume, obtained by multiplying the SOC by soil bulk density and soil layer depth. However, this approach does not take into account the variation in soil bulk density between soils (Balesdent, 1996), which might be a source of errors when soils with very different bulk densities are compared. To eliminate this problem, different soil density values have been used, based on the soil type and standard depth. Thus, to calculate the quantities of organic carbon accumulated in different types of soils, according to the method described by Batjes (1996), the values for each soil type were multiplied by the bulk density and the standard depths. Therefore, the following formula was used:

$$
C-\text { stock } \min =C-\operatorname{con} c \times B D \times d \times C F s t
$$

where $\mathrm{C}$-stockmin is the $\mathrm{C}$ stock in the mineral soil $\left(\mathrm{kg} / \mathrm{m}^{2}\right.$ $\times 10=\mathrm{t} / \mathrm{ha}$ ), $\mathrm{d}$ is the depth class/horizon thickness ( $\mathrm{m}$ ), C-conc is the concentration of organic carbon $(\mathrm{g} / \mathrm{kg}), \mathrm{BD}$ is the bulk density $\left(\mathrm{kg} / \mathrm{dm}^{3}\right)$ and CFst is the correction factor for stoniness.

Bulk density can be estimated using pedo-transfer functions. A typical example of a pedo-transfer function is the Adams (1973) equation:

$$
B D=\frac{100}{\frac{1,72 * \% O C}{0,244}+\frac{100-1,72 * \% O C}{M B D}}
$$

where $\% \mathrm{OC}$ is the percentage of total organic carbon and MBD is the mineral bulk density (usually estimated at 1.33 $\mathrm{kg} / \mathrm{m}^{3}$ or determined based on the 'Mineral Bulk Density Chart' developed by Rawls and Brakensiek, 1985).

\section{Calculating organic C stock on pedogenetic horizons \\ (Method 1)}

The values obtained for organic $\mathrm{C}$ and bulk density were arranged according to soil types and pedogenetic horizons and the mean values were then calculated for minimal depth, maximum depth, organic $\mathrm{C}$ and bulk density. Based on these values and by applying the first formula (1), the organic $\mathrm{C}$ stock to a maximum depth of $1 \mathrm{~m}$ was obtained. 
570

\section{Calculating organic C stock on standard depths \\ (Method 2)}

The database was further structured according to soil type (following Romanian nomenclature, adopted from the FAO) and standard depths (e.g. $0-10 \mathrm{~cm} ; 10-20 \mathrm{~cm} ; 20-40 \mathrm{~cm} ;>40$ $\mathrm{cm}$ ), following European monitoring activity procedure (Cools and De Vos, 2010).

The values of organic $\mathrm{C}$ and bulk density corresponding to the harvesting depths of the soil samples were distributed within one of the standard depths mentioned above. The calculations were thus similar to those of Method 1 .

When the total organic $\mathrm{C}$ stock was calculated, the total depth of soil profiles was taken into consideration. For example: $70 \mathrm{~cm}$ for a rendzic leptosol, $80 \mathrm{~cm}$ for an entic podzol, etc.

\section{Calculating organic $C$ stock using regression equations} (Method3)

The regression equation between the quantity of organic $\mathrm{C}$ and the harvesting depth was calculated for each soil type (since only one value is required, but an interval was registered during harvesting, the middle of this interval was taken; for example, for a sample harvested between 5 and $15 \mathrm{~cm}$, the mean value was 10 $\mathrm{cm})$. A logarithmic equation was used for the regression equation, because it is closer to the real variation of the registered values (Fig. 1).

For each equation, the organic $\mathrm{C}$ quantity was established at depths from 10 to $100 \mathrm{~cm}$, until the depth of $1 \mathrm{~m}$ (e.g. $5 \mathrm{~cm}, 15$ $\mathrm{cm}, 25 \mathrm{~cm}, 35 \mathrm{~cm}, 45 \mathrm{~cm}, 55 \mathrm{~cm}, 65 \mathrm{~cm}, 75 \mathrm{~cm}, 85 \mathrm{~cm}$ and 95 $\mathrm{cm})$. For superficial soils, the calculation depth was that established within Method 2.

Based on these values and the corresponding values for bulk density, the organic $\mathrm{C}$ stock was calculated for all forest soils within Romania. The formula used was the following:

Table 1. Organic C stock calculated on pedogenetical horizons

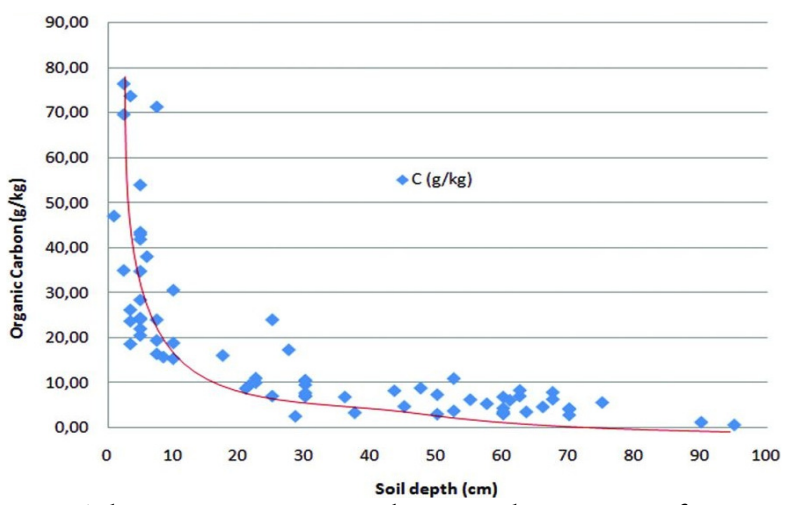

Fig. 1. The regression equation between the quantity of organic $\mathrm{C}$ and the harvesting depth of soil samples, for a haplic luvisol

C stoc $=\mathrm{C}_{\text {concs }} \mathrm{cm} \times \mathrm{BD}_{5 \mathrm{~cm}} \times 1$ (depth in $\left.\mathrm{dm}\right)+\mathrm{C}_{\text {conc15 } \mathrm{cm}} \mathrm{x}$ $\mathrm{BD}_{15 \mathrm{~cm}}+\mathrm{C}_{\mathrm{conc} 25 \mathrm{~cm}} \mathrm{X} \mathrm{BD}_{25 \mathrm{~cm}}+\ldots$

\section{Results and Discussion}

\section{Calculatingorganic Cstock on pedogenetical horizons}

The values obtained for organic $\mathrm{C}$ and bulk density were arranged according to soil types and pedogenetic horizons and the mean values were then calculated for minimal depth, maximum depth, organic $\mathrm{C}$ and bulk density. Based on these values and by applying formula (1), the organic $C$ stock to a maximum depth of $1 \mathrm{~m}$ was obtained (Table 1).

\section{Calculating organic Cstock on standard depths}

When the total organic $\mathrm{C}$ stock was calculated, the total depth of soil profiles was taken into consideration. The obtained results are presented in Table 2 .

\begin{tabular}{|c|c|c|c|c|c|c|c|}
\hline Type of soil & Horizon & No. of values & Min dept $(\mathrm{cm})$ & Max depth $(\mathrm{cm})$ & Organic C $(\mathrm{g} / \mathrm{kg})$ & $\mathrm{BD}\left(\mathrm{kg} / \mathrm{cm}^{3)}\right.$ & Organic C stock ( $\mathrm{t} / \mathrm{ha})$ \\
\hline \multirow{3}{*}{ Fluvisol } & Ao & 235 & 0 & 19 & 24.57 & 1.13 & 55.53 \\
\hline & $\mathrm{A} / \mathrm{C}$ & 17 & 22 & 60 & 15.79 & 1.2 & 37.9 \\
\hline & C & 298 & 33 & 85 & 9.88 & 1.24 & 74.0 \\
\hline \multicolumn{2}{|l|}{ Total fluvisol } & & & & & & 167 \\
\hline \multirow{3}{*}{ Chernozem } & $\mathrm{Am}$ & 68 & 0 & 28 & 30.55 & 1.09 & 99.9 \\
\hline & $\mathrm{A} / \mathrm{C}$ & 49 & 28 & 68 & 15 & 1.2 & 54 \\
\hline & Cca & 33 & 59 & 103 & 13.17 & 1.21 & 63.74 \\
\hline \multicolumn{2}{|c|}{ Total chernozem } & & & & & & 218 \\
\hline \multirow{2}{*}{$\begin{array}{l}\text { Dystric } \\
\text { cambosol }\end{array}$} & Ao & 415 & 0 & 11 & 51.04 & 0.98 & 50.01 \\
\hline & $\mathrm{Bv}$ & 456 & 17 & 76 & 14.53 & 1.21 & 158.23 \\
\hline \multicolumn{2}{|c|}{ Total distryc cambosol } & & & & & & 208 \\
\hline \multirow{2}{*}{$\begin{array}{c}\text { Eutric } \\
\text { cambosol }\end{array}$} & Ao & 372 & 0 & 12 & 42.98 & 1.02 & 87.68 \\
\hline & $\mathrm{Bv}$ & 424 & 19 & 79 & 9.92 & 1.24 & 98.41 \\
\hline \multicolumn{2}{|c|}{ Total eutric cambosol } & & & & & & 186 \\
\hline \multirow{3}{*}{ Phaeozem } & $\mathrm{Am}$ & 239 & 0 & 27 & 29 & 1.1 & 95.7 \\
\hline & $\mathrm{A} / \mathrm{C}$ & 117 & 31 & 82 & 14.16 & 1.2 & 84.96 \\
\hline & $\mathrm{C}$ & 56 & 64 & 105 & 9.54 & 1.24 & 23.66 \\
\hline \multicolumn{2}{|c|}{ Total phaeozem } & & & & & & 204 \\
\hline \multirow{3}{*}{ Haplic luvisol } & Ao & 236 & 0 & 8 & 35.74 & 1.06 & 67.8 \\
\hline & El & 229 & 8 & 39 & 10.06 & 1.24 & 37.42 \\
\hline & $\mathrm{Bt}$ & 222 & 38 & 89 & 5.44 & 1.28 & 41.78 \\
\hline \multicolumn{2}{|c|}{ Total haplic luvisol } & & & & & & 147 \\
\hline \multirow{4}{*}{ Entic podzol } & Aou & 148 & 0 & 15 & 82.45 & 0.83 & 136.87 \\
\hline & $\mathrm{A} / \mathrm{B}$ & 13 & 12 & 33 & 35.97 & 1.05 & 37.77 \\
\hline & Bs & 169 & 18 & 75 & 31.58 & 1.09 & 137.69 \\
\hline & $B / R$ & 11 & 63 & 83 & 14.15 & 1.21 & 51.36 \\
\hline \multicolumn{2}{|c|}{ Total entic podzol } & & & & & & 364 \\
\hline
\end{tabular}


Table 2. Organic C stock calculated on standard depths

\begin{tabular}{|c|c|c|c|c|c|}
\hline Type of soil & Depth $(\mathrm{cm})$ & No. of values & Organic C (g/kg) & $\mathrm{BD}\left(\mathrm{kg} / \mathrm{cm}^{3)}\right.$ & Organic C stock ( $\mathrm{t} / \mathrm{ha})$ \\
\hline \multirow{4}{*}{ Fluvisol } & $0-10$ & 153 & 29.64 & 1.09 & 32 \\
\hline & $10-20$ & 98 & 19.54 & 1.17 & 23 \\
\hline & $20-40$ & 105 & 14.1 & 1.2 & 34 \\
\hline & $40-100$ & 242 & 7.48 & 1.26 & 57 \\
\hline Total fluvisol & & & & & 146 \\
\hline \multirow{4}{*}{ Chernozem } & $0-10$ & 32 & 42.08 & 1.01 & 43 \\
\hline & $10-20$ & 34 & 24.65 & 1.12 & 28 \\
\hline & $20-40$ & 36 & 16.46 & 1.18 & 39 \\
\hline & $40-100$ & 67 & 10.91 & 1.23 & 80 \\
\hline Total chernozem & & & & & 190 \\
\hline \multirow{4}{*}{ Dystric cambosol } & $0-10$ & 398 & 54.65 & 0.96 & 52 \\
\hline & $10-20$ & 116 & 25.45 & 1.13 & 29 \\
\hline & $20-40$ & 163 & 14.56 & 1.2 & 35 \\
\hline & $40-80$ & 227 & 5.9 & 1.27 & 30 \\
\hline Total distric camb. & & & & & 146 \\
\hline \multirow{4}{*}{ Eutric cambosol } & $0-10$ & 347 & 45.27 & 1.07 & 48 \\
\hline & $10-20$ & 68 & 21.33 & 1.14 & 24 \\
\hline & $20-40$ & 148 & 12.89 & 1.21 & 31 \\
\hline & $40-80$ & 272 & 5.77 & 1.27 & 29 \\
\hline Total eutric camb. & & & & & 132 \\
\hline \multirow{4}{*}{ Phaeozem } & $0-10$ & 125 & 39.46 & 1.03 & 41 \\
\hline & $10-20$ & 80 & 21.95 & 1.14 & 25 \\
\hline & $20-40$ & 136 & 15.62 & 1.19 & 37 \\
\hline & $40-100$ & 181 & 8.49 & 1.25 & 64 \\
\hline Total phaeozem & & & & & 167 \\
\hline \multirow{4}{*}{ Haplic luvisol } & $0-10$ & 222 & 36.05 & 1.06 & 38 \\
\hline & $10-20$ & 52 & 17.33 & 1.18 & 20 \\
\hline & $20-40$ & 182 & 8.77 & 1.25 & 22 \\
\hline & $40-90$ & 225 & 4.83 & 1.28 & 31 \\
\hline Total haplic luvisol & & & & & 111 \\
\hline \multirow{4}{*}{ Entic podzol } & $0-10$ & 284 & 84.07 & 0.83 & 70 \\
\hline & $10-20$ & 164 & 61.11 & 0.91 & 56 \\
\hline & $20-40$ & 261 & 35 & 1.06 & 74 \\
\hline & $40-80$ & 192 & 10.69 & 1.23 & 53 \\
\hline Total entic podzol & & & & & 253 \\
\hline
\end{tabular}

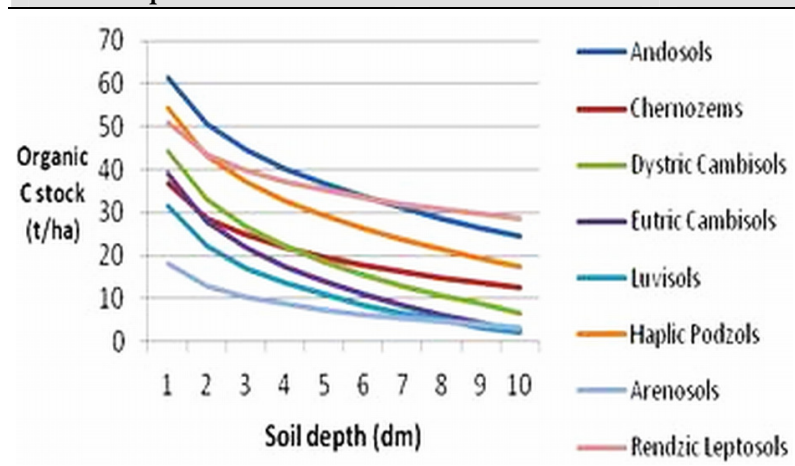

Fig. 2. The variation in organic $\mathrm{C}$ within soil harvesting depth (samples of different forest soils)

Calculating the organic $C$ stock with the help of regression equations

By calculating the variation and standard deviation for Method 1 (calculating organic $\mathrm{C}$ on horizons) and for Method 2 (calculating organic $\mathrm{C}$ on depth), values were very similar in the superior horizons, respectively Ao and the $0-10 \mathrm{~cm}$ layer. However, progressing to inferior horizons, the differences became larger (e.g. for andosol, the standard deviation in the Au horizon was 39.1 (Method 1), whereas it was 38.8 in the $0-10 \mathrm{~cm}$ layer (Method 2). As the depth further increased, the differences became even larger, thus for the Bv horizon, the standard deviation was 17.9 (Method 1) and for a depth of $10-20 \mathrm{~cm}$ it was 11.2 (Method 2); in the
A/R horizon it was 21.1 (Method 1), whereas at a depth of 20 - 40 $\mathrm{cm}$, it was 9.7 (Method 2).

Using Method 2, the variations and standard depths were smaller as the soil depth increased in comparison with those from Method 1 from the inferior horizons. Thus, the data were more homogenous for Method 2.

To calculate the total organic $\mathrm{C}$ stock, the total depth of soil profiles established by Methods 1 and 2 were considered. The results based on the regression equations are shown in Table 3.

The correlation between the quantity of organic $C$ and the sample harvesting depth

The lowest correlations between the quantity of organic $\mathrm{C}$ and the sample harvesting depths (although no values were significant) were recorded for rendzic leptosol (due to the variability of organic $\mathrm{C}$ at the depth of $20-40 \mathrm{~cm}$ ), haplic podzol (due to the variation in soil profile, with a decrease in the Es and an increase in Bhs horizons, which means a different curve to a logarithmic one) and for fluvisol (due to the great variability in the amount of slime material that also contained variable quantities of organic $\mathrm{C}$ ). The strongest correlation was recorded for acid soils (umbric-entic podzol, alosol, entic podzol etc.) (Fig. 2).

Main aspects regarding the approach of different organic $C$ stock calculation methods

Problems encountered for Method 1 (calculating the organic C stock on pedogenetical horizons) refer to several aspects: 
572
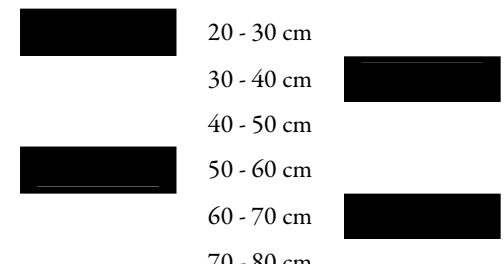

Fig. 3. Harvesting soil samples in the case of thicker horizons (left- the present work method, right- the standard method). The colour black is used to show the location of sample harvesting

- The framing limits of a horizon can lead to significant errors. For example, if for eutric cambosols, based on diagnostic criteria, it was considered that the Ao horizon has a mean depth of $10 \mathrm{~cm}$, whereas the total reserve of organic $C$ was $155 \mathrm{t} / \mathrm{ha}$, while for Ao the medium depth was $20 \mathrm{~cm}$ and organic $\mathrm{C}$ reserve was $186 \mathrm{t} / \mathrm{ha}$;

- The mean limits for framing successive soil horizons do not follow exactly sequentially from one another. For example: $\mathrm{El}=$ $10-45 \mathrm{~cm}, \mathrm{Bt}=32-85 \mathrm{~cm}$. This problem does not exist for soils where the horizons do not have variants of soil subtypes. For example: haplic luvisol, $\mathrm{Ao}=0-8, \mathrm{El}=8-39, \mathrm{Bt}=38$ - 89;

- The dimensional framing of $\mathrm{A} / \mathrm{B}$ transition horizons. In many cases, the transition between horizons was trenchant (A, $B)$, but when transition areas were present $(A / B)$, the dimension of these horizons can partially or totally overlap with A or B horizons;

- Some horizons from the soil subtypes cannot be properly framed as profile depths (because they overlap on other horizons). For example: the $\mathrm{G}$ horizon from gleic fluvisol overlaps with the C horizon;

- The absence of samples for great depths (e.g. depths $>8 \mathrm{~cm}$ for stagnosol).

Aspects encountered applying Method 2 (calculating the organic C stock on standard depths) may be as follows:

- The correct framing on depths for 0 - 10 and $10-20 \mathrm{~cm}$; e.g. Corg $=20.4$ for $0-20 \mathrm{~cm}$ at dystric cambosol, can also be framed at $0-10$, as well as at $10-20 \mathrm{~cm}$;

- The main advantage of this method was that by analysing each value, a better repartition could be realised concerning the harvesting depths, thus modifying the errors that occurred from estimating the depths; e.g. $\mathrm{C}=8.9$ recorded in the field for a dystric cambosol at a depth of $0-6 \mathrm{~cm}$ was, in reality, somewhere between $10-20 \mathrm{~cm}$;

- The large volume of work needed for framing each organic $\mathrm{C}$ value on certain standard depth may be a problem when applying this method.

Problems encountered for Method 3 (calculating the organic C stock using regression equations):

- The wrong estimate of the harvesting depth can lead to significant errors. For example, the value of 48.3 for the depth of $0-25$ might be recorded as $12.5 \mathrm{~cm}$, whereas in reality, it can be harvested at a depth of $5 \mathrm{~cm}$;

- The main advantage is that this method renders the carbon stock precisely at the harvesting depth of the samples (for example: $35 \mathrm{~cm}$ and not the B horizon in Method 1, or 20-40 $\mathrm{cm}$ in Method 2), assuming that the harvesting depth was measured very accurately;

- At some depths (80 - $100 \mathrm{~cm})$, negative values of organic C quantity can sometimes appear (in alosols or haplic luvisols), due
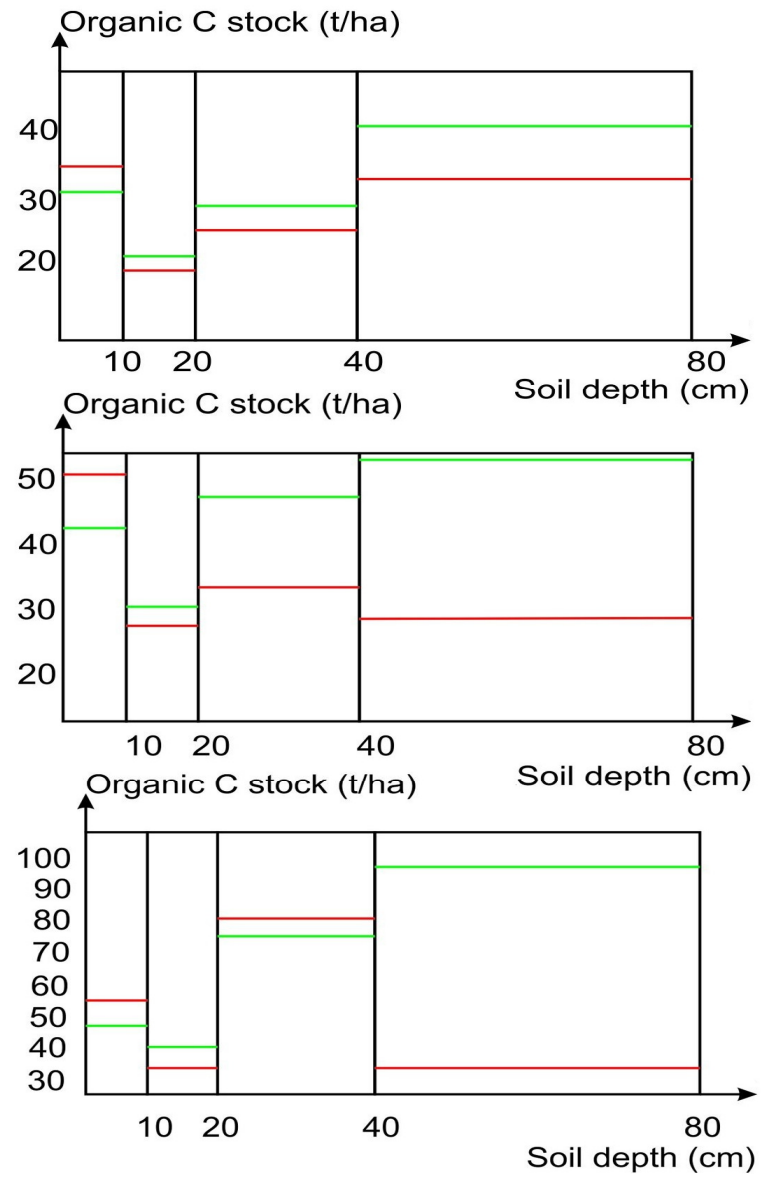

Fig. 4. Comparison between the results obtained by Method 2 (red) and Method 3 (green) for three forest soils (from top to bottom): preluvisol, dystric cambosol, rendzic leptosol

to the regression equation. These values should not be taken into consideration, because the loss of organic C from these calculations is minimal.

\section{Comparison between the methods}

Greater values were always obtained in the current study from Method 1 (calculating the organic $\mathrm{C}$ stock on pedogenetical horizons) than from Method 2 (calculating the organic $\mathrm{C}$ stock on standard depths) (Table 4). These differences were more significant for soils rich in organic $\mathrm{C}$ (andosols, umbric-entic podzols, humic umbrisols or haplic podzols). This situation might be caused by the predominant harvesting of soil samples from the superior part of horizons that are thicker and due to uneven distribution in the case of two samples from the same horizon (Fig. 3).

Thus, calculating the $\mathrm{C}$ stock on pedogenetical horizons leads to an overestimation of the stock (Fig. 4).

For soils with a strong decreasing curve (based on correlation between organic C - soil depth) the differences were very small, whereas for soils with a flattened curve, the differences were greater. The flatter the curve was at higher values for greater harvesting depths, the larger were the differences (rendzic leptosol).

The differences between the two methods increased together with a decrease in the correlation coefficient between the organic $\mathrm{C}$ stock and the sample harvesting depth: $R=0.63$ for preluvisol, 0.58 for dystric cambosol and 0.37 for rendzic leptosol. 
Table 3. Organic C stock calculated using regression equations

\begin{tabular}{|c|c|c|c|c|}
\hline Type of soil & No. of samples & $\mathrm{R}$ & Regression equation & Organic C stock ( $\mathrm{t} / \mathrm{ha})$ \\
\hline Alosol & 71 & -0.69 & $\mathrm{y}=54.9364-28.8542^{*} \log 10(\mathrm{x})$ & 107 \\
\hline Fluvisol & 98 & -0.46 & $\mathrm{Y}=35.9819-14.1809^{*} \log 10(\mathrm{x})$ & 158 \\
\hline Andosol & 66 & -0.53 & $\mathrm{Y}=112.0021-5.3653^{*} \log 10(\mathrm{x})$ & 267 \\
\hline Chernozem & 69 & -0.52 & $\mathrm{Y}=51.5597-20.8498^{*} \log 10(\mathrm{x})$ & 207 \\
\hline Umbric-entic podzol & 45 & -0.76 & $\mathrm{Y}=138.0389-5.0979 * \log 10(\mathrm{x})$ & 280 \\
\hline Dystric cambosol & 900 & -0.58 & $Y=71.3529-33.3716^{*} \log 10(x)$ & 185 \\
\hline Eutric cambosol & 832 & -0.63 & $\mathrm{Y}=61.2257-29.9986^{*} \log 10(\mathrm{x})$ & 146 \\
\hline Phaeozem & 522 & -0.56 & $Y=49.5161-20.6402 * \log 10(x)$ & 190 \\
\hline Gleysol & 121 & -0.49 & $\mathrm{Y}=47.6058-20.0732^{*} \log 10(\mathrm{x})$ & 180 \\
\hline Haplic luvisol & 681 & -0.6 & $\mathrm{Y}=46.1705-23.7455^{*} \log 10(\mathrm{x})$ & 100 \\
\hline Haplic podzol & 105 & -0.4 & $Y=92.9608-39.4508^{*} \log 10(x)$ & 269 \\
\hline Preluvisol & 1183 & -0.63 & $\mathrm{Y}=46.5402-22.7637^{*} \log 10(\mathrm{x})$ & 122 \\
\hline Entic podzol & 329 & -0.67 & $\mathrm{Y}=120.4124-2.1097 * \log 10(\mathrm{x})$ & 315 \\
\hline Arenosol & 139 & -0.53 & $\mathrm{Y}=22.9218-10.3226^{*} \log 10(\mathrm{x})$ & 78 \\
\hline Rendzic leptosol & 162 & -0.37 & $\mathrm{Y}=76.6534-25.1689^{*} \log 10(\mathrm{x})$ & 273 \\
\hline Stagnosol & 70 & -0.65 & $Y=47.1301-22.2707 \log 10(x)$ & 128 \\
\hline Vertisol & 48 & -0.62 & $\mathrm{Y}=39.8113-18.3437 \log 10(\mathrm{x})$ & 116 \\
\hline
\end{tabular}

Table 4. Results and differences between the tested methods

\begin{tabular}{|c|c|c|c|c|c|}
\hline Type of soil & Method 1 & Method 2 & Method 3 & Differences \% between 1 and 2 & Differences $\%$ between 2 and 3 \\
\hline Fluvisol & 167 & 146 & 158 & 13 & 8 \\
\hline Andosol & 290 & 218 & 267 & 33 & 9 \\
\hline Chernozem & 218 & 190 & 207 & 13 & 8 \\
\hline Umbric-entic podzol & 209 & 216 & 280 & 34 & 23 \\
\hline Dystric cambosol & 208 & 146 & 185 & 30 & 21 \\
\hline Eutric cambosol & 186 & 132 & 146 & 29 & 10 \\
\hline Phaeozem & 204 & 167 & 190 & 18 & 12 \\
\hline Gleysol & 200 & 155 & 180 & 29 & 14 \\
\hline Haplic luvisol & 147 & 111 & 100 & 24 & 11 \\
\hline Haplic podzol & 344 & 259 & 269 & 25 & 4 \\
\hline Preluvisol & 124 & 124 & 122 & 0 & 2 \\
\hline Entic podzol & 364 & 253 & 315 & 30 & 20 \\
\hline Arenosol & 93 & 79 & 78 & 15 & 1 \\
\hline Rendzic leptosol & 287 & 213 & 273 & 26 & 22 \\
\hline Stagnosol & 144 & 122 & 128 & 15 & 5 \\
\hline Vertisol & 150 & 106 & 116 & 29 & 9 \\
\hline
\end{tabular}

The differences between Method 1 and Method 2 were high (up to $34 \%$ for andosol and umbric-entic podzol), but those between Methods 2 and 3 were smaller (a maximum of 22-23\% for of umbric-entic podzol and rendzic leptosol). The differences between methods were significantly lower for andosol (33-9\%), arenosol (15-1\%) and vertisol (29-9\%). Small decreases were observed for rendzic leptosol (26-22\%).

The differences were high between the results based on pedogenetical horizons and those of the method using standard depths (these differences were larger for soils rich in organic C: andosol, umbric-entic podzol, humic umbrisol or haplic podzols, and reached $46 \%$ for andosol and umbric-entic podzol). However, the differences were smaller between the methods using standard depths and those using regression equations (a maximum of 22$23 \%$ for umbric-entic podzol and rendzic leptosols). The differences between the two methods were considerably lower for andosol (33-9\%), arenosol (15-1\%) and vertisol (29-9\%), while small decreases were recorded for rendzic leptosols (26-22\%).

For many analysed samples, the correlation between the sample harvesting depth and the stock of organic $\mathrm{C}$ was significant for all types of soil. However, lower correlation coefficients were observed for rendzic leptosol (due to the large variability in organic $\mathrm{C}$ quantity at depths of $20-40 \mathrm{~cm}$ ), haplic podzol (due to variation in the soil profile, with a decrease in the Es horizon and an increase in Bhs), and fluvisol (due to the great variability of slime material that also contains variable amounts of organic C). follows:

- Method 3 allows a mean curve to be realised for all the points; it is recommended to realise arithmetical means for some depths;

- The chosen depths within Method 2 (0 - 10, 10 - 20, 20 - 40 and $40-100 \mathrm{~cm}$ ) corresponded to different variations in the quantity of organic C: a strong decrease for the first two intervals and alow decrease for the subsequent intervals;

- For Method2, the number of intervals for which the organic C stock was calculated increased. For example, for dystric cambosol, Method 1 used three intervals (Ao, Ao/Bv, Bv), whereas the second method generated four intervals $(0$ - 10, 10 - 20, 20 - 40, 40 - 100 $\mathrm{cm}$ ), thus offering more reliable data;

- Within Method 3 it was assumed that the soil sample was homogenous throughout the entire harvesting depth (for example, for $20-40 \mathrm{~cm}$, a similar soil quantity should be taken throughout the mentioned interval, when in reality, the quantity is taken only from the upper part). This leads to an overvaluation of the carbon stock;

- By applying Method 2, possible errors in writing harvesting depths can be identified. An example of adjustment: the $\mathrm{C}$ org = 24.4 between $5-85 \mathrm{~cm}$, with a mean of $45 \mathrm{~cm}$, but in reality sample was harvested at a depth between $10-20 \mathrm{~cm}$ (the entire thickness of the horizon was recorded, but the sample was harvested only from the upper part); 
574

- For some soils, regardless of the number of soil samples harvested, the correlation coefficient for the curves established through Method 3 was low due to some properties of these soils. However, Method 3 is easier to apply, because Method 2 requires the establishment of each value to a standard depth, which implies a long time and a lot of effort.

\section{Conclusions}

Calculating the stock of organic carbon based on pedogenetic horizons, as well as the method using regression equations led to considerable overestimation of this stock. Taking into consideration that the harvesting of soil samples was not uniform for some depth intervals, and that by distributing organic $\mathrm{C}$ quantities on standard depths, more categories were obtained than by registering these values on pedogenetic horizons, it can be concluded that the best method for evaluating the organic $\mathrm{C}$ stock is one that distributes the obtained values onto the following standard depths: $0-10 \mathrm{~cm} ; 10-20 \mathrm{~cm} ; 20-40 \mathrm{~cm} ;>40 \mathrm{~cm}$. Method 2 (using standard depths) was more accurate for evaluating the organic $\mathrm{C}$ quantity, because the variation and standard deviations were lower compared to those obtained from Method 1 (based on pedogenetic horizons) for most all the studied soil types. Even so, depending on the samples and the procedure during harvesting, all methods present different criteria which correspond to various results and have therefore objective representations of the data collected.

\section{References}

Adams WA (1973). The effect of organic matter on the bulk and true densities of some uncultivated podzolic soils. Journal of Soil Science 24(21):10-17.

Amichev B, Galbraith JM (2004). A revised methodology for estimation of forest soil carbon from spatial soils and forest inventory data set. Environmental Management 33:7486.

Aticho A (2013). Evaluating organic carbon storage capacity of forest soil. Case study in Kafa Zone Bita District, Southwestern Ethiopia. American Eurasian Journal of Agriculture and Environmental Science 13(1):95-100.

Batjes NH (2002). Carbon and nitrogen stocks in the soils of Central and Eastern Europe. Soil Use and Management 18:324329.

Balesdent J (1996). Un point sur l'evolution des reserves organiques des sols en France. Etude et Gestion des Sols 3:245-260.

Bernoux M, Carvalho MCS, Volkoff B, Cerri CC (2002). Brazil's soil carbon stock. Soil Science Society of America Journal 66(3):888-896.

Brahim N, Bernoux M, Blavet D, Gallali T (2010). Tunisian soil organic carbon stocks. International Journal of Soil Science 5:3440.

Cambule AH, Rossiter DG, Stoorvogel JJ, Smaling EMA (2014). Soil organic carbon stocks in the Limpopo National Park, Mozambique: Amount, spatial distribution and uncertainty. Geoderma 213:46-56.

Campbell JE, Moen JC, Ney RA, Schnoor JL (2008). Comparison of coefficient and GIS-based methodologies for regional estimates of forest soil carbon stocks. Environmental Pollution 152:267-273.

Cools N, De Vos B (2010). 6th FSCC Interlaboratory Comparison 2009, Instituut voor Natuur en Bosonderzoek, Belgium.

Davidson EA, Lefebvre PA (1993). Estimating regional carbonstock and spatially covarying edaphic factors using soil maps at three scales. Biogeochemistry 22:107-131.
Dey SK (2005). A preliminary estimation of carbon stock sequestrated through rubber (Hevea brasiliensis) plantation in North Eastern regional of India Indian Forester 131(11):1429-1436.

De Vries W, Vel E, Reinds GJ, Deelstra H, Klap JM, Leeters EEJM, ... Haussmann T (2003). Intensive monitoring of forest ecosystems in Europe: 1. Objectives, set-up and evaluation strategy. Forest Ecology and Management 174(1):77-95.

De Vries W, Reinds GJ, Vel E (2003). Intensive monitoring of forest ecosystems in Europe: 2: Atmospheric deposition and its impacts on soil solution chemistry. Forest Ecology and Management 174(1):97115.

Dinca L, Sparchez Gh, Dinca M, Blujdea V (2012). Organic carbon concentrations and stocks in Romanian mineral forest soils. Annals of Forest Research 55(2):229-241.

Djukic I, Zehetner F, Tatzber M, Gerzabek MH (2010). Soil organicmatter stocks and characteristics along an Alpine elevation gradient. Journal of Plant Nutrition and Soil Science 173(1):30-38.

Don A, Schumacher J, Freibauer A (2011). Impact of tropical land-use change on soil organic carbon stocks-a meta-analysis. Global Change Biology 17:1658-1670.

Egli M, Sartori G, Mirabella A, Favilli F, Giaccai D, Delbos E (2009). Effect of north and south exposure on organic matter in high Alpine soils. Geoderma 149:124-136.

Ellert BH, Janzen HH, Entz T (2002). Assessment of a method to measure temporal change in soil carbon storage. Soil Science Society of America Journal 66:1687-1695.

Eswaran H, Reich PF, Kimble JM, Beinroth FH, Padmanabhan E, Moncharoen P (1999). Global climate change and pedogenic carbonates. Lal R(Ed).Lewis Publishers, USA pp 15-25.

Fahey TJ, Groffman PM, Holmes RT, Schwarz PA, Siccama TG, Driscoll CT, Likens GE, Campbell J, Johnson CE, Aber JD (2005). The biogeochemistry of carbon at Hubbard Brook. Biogeochemistry 75:109-176.

Fantappiè M, L'Abate G, Costantini EAC (2011). The influence of climate change on the soil organic carbon content in Italy from 1961 to 2008. Geomorphology 135:343-352.

Giliba R, Boon E, Kayombo C, Musamba E, Kashindye A, Shayo F (2011). Species composition, richness and diversity in Miombo woodland of Bereku forest reserve. Tanzania. Journal of Biodiversity 2(1):1-7.

Gorte WR (2009). Carbon sequestration in forests. Congressional Research Service. The Library Congress, Washington DC USA, Diane Publishing.

Grand S, Lavkulich LM (2011). Depth distribution and predictors of soil organic carbon in Podzols of a forested watershed in South-western Canada. Journal of Soil Science 176(4):164174.

Hattar BI, Taimeh AY, Ziadat FM (2010). Variation in soil chemical properties along toposequences in an arid region of the Levant. Catena 83:34-45.

Hoffmann U, Hoffmann T, Johnson EA, Kuhn NJ (2014). Assessment of variability and uncertainty of soil organic carbon in a mountainous boreal forest (Canadian Rocky Mountains, Alberta). Catena 113:107-112.

Jandl R, Rodeghiero M, Martinez C, Cotrufo MF, Bampa F, van 
Wesemael B, Harrison RB, Guerrini IA, Richter D de B, Rustad L, Lorenz K, Chabbi A, Miglietta F (2014). Current status, uncertainty and future needs in soil organic carbon monitoring. Science of the Total Environment 468:376-383.

Johnson DW, Curtis PS (2001). Effects of forest management on soil C and $\mathrm{N}$ storage: meta analysis. Forest Ecology and Management 140:227-238.

Kadovič R, Belanovič S, Knezevič M, Danilovič M, Kosanin O, Beloica J (2012). Organic carbon stock in some forest soils in Serbia. Bulletin of the Faculty of Forestry 105:81-98.

Karchegani PM, Ayoub S, Mosaddeghi MR, Honarjoo N (2012). Soil organic carbon pools in particle size fractions as affected by slope gradient and land use change in Hilly Regions, Western Iran. Journal of Mountain Science 9(1):87-95.

Kern JS (1994). Spatial patterns of soil organic carbon in the contiguous United States. Soil Science Society of America Journal 58(2):439-455.

Koulouri M, Giourga C (2007). Land abandonment and slope gradient as key factors of soil erosion in Mediterranean terraced lands. Catena 69:274-281.

Lal R (2005). Forest soils and carbon sequestration. Forest Ecology and Management 220:242-258.

NegiSS, Gupta MK, SharmaSD (2013). Sequestered organic carbon pool in the forest soils of Uttarakhand State, India. International Journal of Science, Environment and Technology 2(3):510-520.

Paul KI, Polgase PJ, Nyakuengama JG, Khanna PK (2002). Change in soil carbon following afforestation. Forest Ecology and Management 168:241-257.

Peltoniemi M, Thurig E, Ogle S, Palosuo T, Schrumpf M, Wutzler T, ... Mäkipää R (2007). Models in country scale carbon accounting of forest soils. Silva Fennica 41:575-602.

Post WM, Emanuel WR, Zinke PJ, Stangenberger AG (1982). Soil carbon pools and world life zones. Nature 298(8):156-159.

Prentice IC, Farquhar GD, Fasham MJR, Goulden ML, Heimann M, Jaramillo VJ, ... Wallace DW (2001). The carbon cycle and atmospheric carbon dioxide. Climate Change 2001: The Scientific Basis IPCC. Cambridge Univ Press Cambridge UKpp 185-237.

Rojas M, Jordán A, Zavala LM, Rosa DDL, Abd-Elmabod SK, Romero MA (2012). Organic carbon stocks in Mediterranean soil types under different land uses (Southern Spain). Solid Earth 3:375-386.

Seibert J, Stendahl J, Sørensen R (2007). Topographical influences on soil properties in boreal forests. Geoderma 141:139-148.

Sombroek WG, Nachtergaele FO, Hebel A (1993). Amounts, dynamics and sequestering of carbon in tropical and subtropical soils. Ambio 22:417-426.

Sreekanth NP, Shanthi PV, Babu P, Thomas AP (2013). Soil carbon alterations of selected forest types as an environmental feedback to climate change. International Journal of Environmental Sciences 3(5):1516-1530.

Swift RS (2001). Sequestration of carbon by soil. Soil Science 166:858871.
Stockmann U, Adams MA, Crawford JW, Field DJ, Henakaarchchi N, Jenkins M, Jeffery S, Verheijen FGA, van der Velde M, Bastos AC (2013). The knowns, known unknowns and unknowns of sequestration of soil organic carbon. Agriculture, Ecosystems \& Environment 164:80-99.

TangJW, Yin JX, Qi JF, Jepsen MR, Lü TT (2012). Ecosystem carbon storage of tropical forests over limestone in Xishuangbanna, SW China. Journal of Tropical Forest Science 24(3):399-407.

UNFCCC - United Nations Economic Commission for Europe Convention on Long-Range Transboundary Air Pollution. International Co-operative Programme on Assessment and Monitoring of Air Pollution Effects on Forests (2010). Manual on methods and criteria for harmonized sampling, assessment, monitoring and analysis of the effects of air pollution on forests. Part III a Sampling and Analysis of Soil, 117. Elaborated by: Expert Panel on Soil Forest Soil Co-ordinating Centre, Research Institute for Nature and Forest, Belgium.

Wang Z, Liu GB, Xu MX,ZhangJ, Wang Y, TangL (2012). Temporal and spatial variations in soil organic carbon sequestration following re-vegetation in the hilly Loess Plateau, China. Catena 99:26-33.

Watson RT, Noble IR, Bolin B, Ravindranath NH, Verardo DJ, Dokken DJ (2000). Land use, uand-use change, and forestry. Cambridge University Press Cambridge.

Whitehead D (2011). Forests as carbon sinks- benefits and consequences. Tree Physiology 31:893-902.

Wiesmeier M, Spörlein P, Geuß U, Hangen E, Haug S, Reischl A, Bernd S, Margit VL, Kögel-Knabner I (2012). Soil organic carbon stocks in southeast Germany (Bavaria) as affected by land use, soil type and sampling depth. Global Change Biology 18(7):2233-2245.

Woollen E, Ryan CM, Williams M (2012). Carbon stocks in an African woodland landscape: spatial distribution and scales of variation. Ecosystems 15(5):804-818.

Xiaojun N, Jianhui Z, Zhengan S (2013). Dynamics of soil organic carbon and microbial biomass carbon in relation to water Erosion and Tillage Erosion. PLoS ONE 8(5):1-7.

Yanai RD, Arthur MA, Siccama TG, Federer CA (2000). Challenges of measuring forest floor organic matter dynamics: repeated measures from a chronosequence. Forest Ecology Management 138:273-283.

Yao MK, Angui PKT, Konaté S, Tondoh JE, Tano Y, Abbadie L, Benest D (2010). Effects of land use types on soil organic carbon and nitrogen dynamics in Mid-West Cote d'Ivoire. European Journal of Scientific Research 40(2):211-222.

Yoo K, Amundson R, Heimsath AM, Dietrich WE (2006). Spatial patterns of soil organic carbon on hill slopes: integrating geomorphic processes and the biological C cycle. Geoderma 130:47-65.

Yuan Z, Antonio G, Fei L, Ji Y, Shuai S, Xugao W, Miao W, Zhanqing $H$ (2013). Soil organic carbon in an old-growth temperate forest: Spatial pattern, determinants and bias in its quantification. Geoderma 195(196):48-55. 